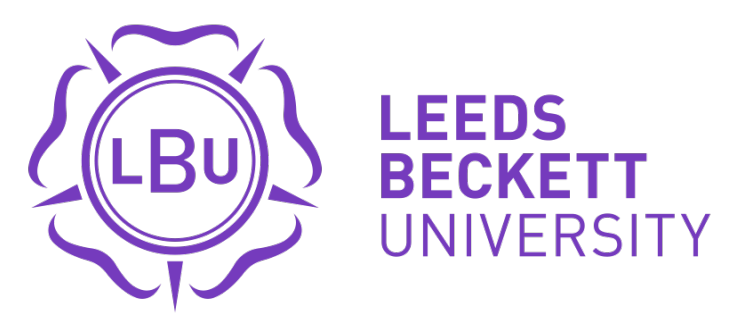

Citation:

Bradley, Q (2014) Bringing democracy back home: Community localism and the domestication of political space. Environment and Planning D: Society and Space, 32 (4). 642 - 657. ISSN 0263-7758 DOI: https://doi.org/10.1068/d17312

Link to Leeds Beckett Repository record:

https://eprints.leedsbeckett.ac.uk/id/eprint/71/

Document Version:

Article (Accepted Version)

The aim of the Leeds Beckett Repository is to provide open access to our research, as required by funder policies and permitted by publishers and copyright law.

The Leeds Beckett repository holds a wide range of publications, each of which has been checked for copyright and the relevant embargo period has been applied by the Research Services team.

We operate on a standard take-down policy. If you are the author or publisher of an output and you would like it removed from the repository, please contact us and we will investigate on a case-by-case basis.

Each thesis in the repository has been cleared where necessary by the author for third party copyright. If you would like a thesis to be removed from the repository or believe there is an issue with copyright, please contact us on openaccess@leedsbeckett.ac.uk and we will investigate on a case-by-case basis. 


\section{Bringing democracy back home: community localism and the domestication of political space}

Bradley, Q (2014) Bringing democracy back home: community localism and the domestication of political space. Environment \& Planning D: Society \& Space. Vol.32 No. 4: 642-657

\section{$\underline{\text { Abstract }}$}

Strategies of localism have constituted the community as a metaphor for democracy and empowerment as part of a wider reordering of state institutions and state power. In conflating the smallest scale with increased participation, however, community localism provides a framework through which the power of socio-spatial positioning might be made vulnerable to resistance and change. This paper identifies four spatial practices through which marginalised communities apply the technology of localism to challenge the limitations of their positioning and imprint promises of empowerment and democracy on space. Drawing on the work of Judith Butler the paper theorises these practices as the incursion into the public realm of regulatory norms related to domestic and private spaces, rendering political space familiar and malleable, and suggesting that power and decision-making can be brought within reach. It is argued that these spatial practices of community rehearse a more fundamental transformation of the political ordering of space than that authorised by the state strategies of localism. 


\section{$\underline{\text { Introduction }}$}

A promise to devolve decision-making to local communities has been a constant theme in a wide-ranging transformation of state institutions and state relations of government into new assemblages of distributed governance (Swyngedouw 2004; Allen \& Cochrane 2010). These political strategies of localism attribute democratic value to scalar constructions in a technology of spatial governmentality (Gibson 2001). Localism hails communities as subjects and agents of governance within reiterative practices intended to produce the embodiment of a new public (Newman \& Clarke 2009). In constituting the local as a metaphor for democracy and empowerment, however, localism foregrounds the pivotal role played by place and scale in cementing social differentiation and in naturalising power relations (Marston 2000). A rationality of governance that seeks to construct a new order of political space, provides unbidden a discourse through which socio-spatial positionalities are made vulnerable to resistance and change (Leitner, Sheppard \& Sziarto 2008).

This paper addresses strategies of localism in England, where the Coalition government's Localism Act 2011 exemplifies the conflation of democracy with the local scale and place-based imaginaries (Painter, Orton et al 2011). By popularising a suite of 'rights' made available to community organisations, it is argued that the Localism Act authorises a performative enactment of democracy, citizenship and the 'public' through the lived experience of place (Dikec 2012). This paper identifies four spatial practices through which 
marginalised communities apply the technology of localism to challenge the limitations of their socio-spatial positioning and imprint promises of empowerment and democracy on space. These practices are theorised as the licensed incursion across a gendered divide of regulatory norms associated with domestic spaces. This domestication of political space enables questions of democratic governance and public participation to be performatively enacted as matters of household economy and neighbourly relations. The spatial practices of community localism are seen to construct the local as democratic and to rehearse a scalar imaginary of participatory governance that represents a more fundamental transformation of the political ordering of space than that authorised by governmental strategies.

The argument is developed from a study of community organisations in England engaged in the local management of public or quasi-public housing services. The research is drawn from focus groups and interviews with 151 community activists in social housing, conducted in four cities across England and at three national conferences undertaken between 2008 and 2012 . The data collection thus spans the localism strategies of the UK Labour government and the initial years of the Coalition government which saw the introduction of the Localism Act in England. The focus groups and interviews sought to explore the strategies emerging from the projects of community enabled by localism. The research findings revealed a significant convergence of opinion evidenced across the focus groups and supported in each narrative (Bradley 2012). To give clear voice to the counter narratives of localism, this paper presents an in-depth study of four of those groups. The 
selection of groups was made in order to clarify and contextualise assertions common across the research sample, and to provide a consistent narrative coupled with insightful analysis of the shared themes. These community groups have exercised the rights of localism to take over the management of social housing estates, or to take ownership of public assets into local trust. They were established to provide democratic representation in the new spatial configurations of local strategic partnerships and regional government. Narratives from these groups are analysed through a dialogue between the work of feminist and queer theorist Judith Butler and the writings of Henri Lefebvre on the production of space. The paper maintains that the imaginaries that emerge demonstrate a desire for a more radical transformation of power than that legitimised by the rationalities of localism; a desire that might signal a wider challenge to the reordering of political space.

The first section of the paper explores the rationalities of community localism (Hildreth 2011) and identifies the contradictions and exclusions that constitute its instability, particularly in its address to the political and spatial demarcation of community as a domestic economy of care. The next section extends this theoretical approach to cast localism as the performative construction of subjectivities through the regulation of spatial effects. Drawing on the work of Judith Butler, it examines the reiterative practices that challenge socio-spatial positioning and enable the transgression of spatial boundaries. The paper then applies this analytical framework to its fieldwork in four sections that chart the domestication of public space, the enactment of place as nearness and participation as neighbouring, the construction of a political imaginary of 
participatory governance, and the performance of governance as a process of neighbourly exchange. The paper concludes with an assessment of the new publics that are enacted through community localism and the impact of these spatial effects on the state rationality of localism.

\section{Communities and the reordering of public space}

Strategies of localism have been central to a political restructuring of state power since the 1970s and have promised 'a reordering of public space' (Mohan \& Stokke 2000: 250), attributing political content to a particular spatial form in their conflation of the local with better and more democratic governance (Purcell 2006; Painter, Orton et al 2011). In Britain localism emerged in the early 1970 s in housing policy that enabled elected community organisations to take over the running of their neighbourhoods with delegated budgets and their own staff teams. Funding to support tenants interested in exploring local management was made available in 1986 and since 1994 tenants in municipal rented housing have had a statutory Right to Manage, while voluntary management options were extended to all social housing tenants in 2008 (CLG 2007a). Under Labour governments from 1997 to 2010 a programme of centrally-driven localism displaced state functions onto devolved parliaments and regional assemblies, but also onto local strategic partnerships and neighbourhood management boards, ensuring the outsourcing of public delivery to private and community interests through a regulatory matrix of targets and inspections (Newman et al 2004). In this strategy of 'community localism' (Hildreth 2011), Labour pledged to 
strengthen local democracy by providing a limited suite of rights to community groups to exert pressure on local authorities. These fledgling measures were reinvigorated by the Coalition Government in the Localism Act 2011, in a more defined package that increased the expectations on the community as subject and agent of governance but abandoned the regime of national standards of public service that had suggested some degree of equity in delivery (Clarke \& Cochrane 2013). The Localism Act (2011) promised to 'shift power away from central government and pass it to local people and community groups' (Pickles 2010), applying assertions of the primacy of local knowledge, the enterprising effect of association and the supposed ethical value of belonging as weapons against collective provision, social insurance and a redistributive state (Hall \& Massey 2010; Featherstone et al 2012). To this apparent end the Act introduced to England four new 'community rights' which presented community groups as the principal beneficiaries of devolved governance and handed them the power to initiate neighbourhood plans, trigger consent for new-build projects, be included as potential bidders for the disposal of public assets, and challenge local authorities to take over public services. Minister of State for Decentralisation in 2011, Greg Clark MP claimed these measures would promote the sense of participation and involvement on which a healthy democracy thrives' (CLG 2011: 1).

Under the Coalition government 'community localism' appears as a scalar construction that addresses neighbourhood organisations as a model for behavioural change to accompany a societal reorientation towards the market as a model for society (Delaney \& Leitner 1997; Raco 2003b). The promise to 
move decision-making closer to the people (Westwood 2011), to 'a spatial scale closer to people's felt sense of identity' (Stoker 2004: 125), provides the rationale for a restructuring of the relationship between the state and public services. The rights of the Localism Act address community groups as the potential providers and trustees of public services and assets, although the main beneficiaries are the multi-national companies and global finance markets involved in privatisation and outsourcing (Fyfe 2005). The shift from a redistributive state to one that celebrates market dynamics is presented as a transfer of responsibility from the state to the community; with community organisations serving as a reassuringly familiar proxy for a residual public sector (Hall \& Massey 2010).

As government strategy, community localism draws on competing traditions of democratic thought and cites, in an attempt to regulate, a long tradition of grass roots activism and neighbourhood campaigns focused on the local welfare state (Williams 1993). The ability of community campaigners to move fluidly from contesting these local services to governing and running them, and back again (Newman 2012), has been a subject of particular commentary among feminist scholars (Martin 2002; Staeheli 2002). The community has been theorised as a liminal space between private and public, an invited space where domestic agency encounters the technologies of government (Jupp 2010). This spatial demarcation of community is the artificial result of the gendered exclusion of domestic and neighbourly care from the dominant narratives of political economy. The segregation of unpaid care work on the other side of 'the international division of labour'(Spivak 2010: 41) creates an 
exclusion zone with a porous boundary; a destination for the outsourcing of welfare services, and a demarcated territory for the governance of behaviour. In strategies of localism, the concept of community has come to stand for moral order; the locale of social responsibility and behavioural norms (Rose 1999; Cochrane 2003; Clarke 2009). 'Community' marks the place where the domestic economy of housework, parental discipline, the bonds of reciprocity and institutional authority all meet to establish the moral bedrock of society, and communities have become therefore 'the instrument through which governments focus their strategies for controlling and regulating social conduct' (Mooney \& Neal 2009: 24). Localism relocates the domestic norms of a gendered private space to the public sphere, while invoking political norms in a domestic hinterland, addressing parenting behaviour and personal health as targets of governance, while promising that politics can be brought within reach and made subject to the rhythms of daily interaction (Jupp 2010).

Mobilisations around place as community have, if anything, been renewed by the ubiquity of the concept in the government discourse of localism (Brent 2009), and the claim to represent, recover, or build community legitimises campaigners and interest groups, and lends urban social movements a powerful cultural capital (Cohen 1997). Community action manifests itself as an ethic of care extended into the public sphere. It appears to mobilise household reproductive labour as a model of co-operation on which to reconstruct society (Abel \& Nelson 1990). It borrows from an economy of reciprocity (Polanyi 1957) celebrated in the community studies literature of the 1950s (Hoggart 1957; Young \& Wilmot 1962) exemplified by the informal 
provision, most often by women, of material and immaterial help through extended family and neighbourhood networks (Williams \& Windebank 2000). The high levels of trust necessary to support this economy of care were founded on the geographical immobility of women (McCulloch 1997), and developed in the absence of alternative means of surviving 'as an extended subterranean chain' of services and good deeds (Bulmer 1986: 112). This gift relationship (Titmuss 1970) is what Raymond Williams called 'the positive practice of neighbourhood' that aims to foster the social relations of community as a model for the collective organisation of society; 'the basic collective idea' that 'the provision of the means of life will, alike in production and distribution, be collective and mutual' (Williams 1958: 326). It is also, and paradoxically, a relationship that can be commodified in the form of social capital, an adaptable coinage that awards an exchange value to economies based on use value (Portes 1998), and that resonates with governmental discourses of responsibility, enterprise and active citizenship. The political technology of localism gives regulatory license to community action at the same time as it seeks to embrace communities as the embodiment of a responsible and governable public.

\section{The subjectivities of localism}

The spatial practices of localism are theorised here as performative enactments of power relations that produce social identity and social space through the citation of regulatory norms. This theoretical framework develops 
the application in human geography of Judith Butler's theory of performativity to understand how regulatory norms are spatially enacted and to conceptualise space as constructed through reiterative practices (Gregson \& Rose 2000; Thrift \& Dewsbury 2000; Houston \& Pulido 2002; Thomas 2004; Kaiser \& Nikiforova 2008). Some challenging parallels have been advanced between Butler's thesis and the work of Henri Lefebvre on the production of space (Conlon 2004; Tyler \& Cohen 2010), and, while it is important to clarify the fundamental differences and divergences between the two theorists, both Butler and Lefebvre understood subjectivity and subject formation as embodied spatial constructions and space as citational. A critical reading of these areas of convergence may help to clarify the processes of socio-spatial positioning under localism and theorise their instability.

In her theory of the performative, Butler argued that socio-spatial positioning (her focus was on the gendered body) is made concrete through the repeated citation of regulatory norms. Drawing on the power of performative speech to bestow identity through such phrases as 'I name this ship' Butler argued that regulatory discourse does not simply describe a situation or an action, it calls into effect the subject relations it names. Subjectivity is constructed as the embodiment of regulated space by the power of this citation, as Butler (1997: 10) maintained: 'Individuals come to occupy the site of the subject (the subject simultaneously emerges as a "site")'. In The Production of Space Lefebvre argued similarly that subjectivity is materialised through the citation of a spatial code or system of space. Subjects accede to 'their space and to their status as subjects acting within that space' by means of this code (Lefebvre 
1991: 16-17), and, as Lefebvre later explained, 'all 'subjects' are situated in a space in which they must either recognise themselves or lose themselves' (Lefebvre 1991: 35). Common to both theorists was an understanding that the subject is constituted as an embodiment of space, within the specific limitations of that space, as a result of signifying practices that naturalise their effects so that space is seen as empty and external and the subject appears as agent of its own will (McCann 1999).

Socio-spatial positioning is produced and reproduced through 'a regularised and constrained repetition of norms' (Butler 1993: 95) and the necessity for continual iteration emphasises the impermanence of subject formation. The opportunity for subverting the meaning of spaces, for occupying them in ways that might challenge their normative use and restrictions, lies in the potential for reiteration to bring change. The accent here is on the active and emergent nature of spaces (Jupp 2008: 334); they are continuously subject to reproduction and reinterpretation that projects 'the instability and incompleteness of subject-formation' (Butler 1993: 226). While Butler does not provide a specific source for this instability other than the potential for discourse to have more meanings than intended, Lefebvre's dialectical triad of space as conceived, perceived and lived, can provide a conceptual model for theorising the unstable processes involved (Lefebvre 1991). This triad represents a complex assemblage of coexisting and overlapping modes of spatial production, but it can be applied usefully to assess the separate processes at play within the citation of spatial norms, and to consider each process as individually subject to reiteration. Every mode of spatial production 
presents instabilities, its 'gaps and fissures' (Butler 1993: 10) that may be opened by reiterative practice. Conceptions, perceptions and practices may be affected by reiteration separately and cumulatively to produce instability and the potential for transgression. In conceptualising his triad Lefebvre located the motor for reiterative change in lived space, or representational space that 'the imagination seeks to change and appropriate' (Lefebvre 1991: 39). He recognised that the 'living' of space is coloured by the imagination, and by memories and emotional associations, and that this repeated 'living' has the potential to produce some variance in the process through which space is reproduced. Imaginary associations and interpretations are an outcome of the everyday reiterative practices that make space familiar, and can change the content and meaning of spaces. Reiteration has been identified as the process whereby space becomes place (Cresswell 2004) and for Yi-Fu Tuan, repeated experience, daily routines and established paths transform space so that it 'gets under the skin' and becomes a 'field of care' (Tuan 1979: 418). This is a practise of domestication, of making space familiar so that symbolic representations are cited to enact wider capabilities and enlarge the range of permitted actions. In the rationalities of community localism, the consequence of this process of domestication has been registered as a breach of spatial boundaries, or the act of jumping scale (Smith 1993; Clark 1994). It can be theorised as a licensed incursion into the public realm of citational practices related to domestic and private spaces, and as a breach in the global gendered division between household reproductive labour and the dominant political economy (Spivak 2010). Localism extends an invitation to superimpose the ethics of domestic and 
neighbourly care on the spatial constructions of governance (Staeheli 2002); it suggests that public space can be enacted as domestic and familiar, and that power and decision-making can be brought within reach. In doing so, it locates political space within familiar patterns of social interaction and gives license to a symbolic substitution of regulatory norms to enact questions of power and governance on a domestic scale. These domesticating practices of community localism accompany, as ambiguous companions, the territorialisation of state power that localism engenders, and they are confined within the regulatory parameters of devolved authority. In the analysis of fieldwork that follows, they can be identified as discursive devices through which the boundaries of political space are talked into new alignments. They indicate breaches in socio-spatial positioning through which resident-led organisations attempt to construct the local scale as both democratic and empowering within the strategy of community localism as defined and bounded by the state.

\section{Extending domestic space}

In a city in the north of England, members of a Tenant Management Organisation, running a social housing estate of 2000 homes on behalf of the local authority, are discussing their plans for the locality. Christine, who is in her early 50 s, is very clear about what she wants to do as the new chair of the management board: 
I know where I want to be and what I want to do and I won't be sidetracked. I want to get the community to how I remember the community round here being, not like it is now.

In the claim she makes on space Christine envisages a process of social change and draws on familial memories to cast herself as the regulator of conduct in the streets and the neighbourhood. She extends authority drawn from the domestic sphere and applies it to a 2000 home estate (Clarke 2009). Localism provides the licence for this scalar jump (Smith 1993) from personal ethics into a manifesto for socio-spatial transformation that Christine sets out clearly:

We should be able to walk out of our front door in comfort and feel safe.

We should be able to walk up and down without fear of intimidation, and the elderly should feel safe. And that's what I'm hoping to achieve, to get this community back to how it were where people are not frightened, and I think I might get there eventually.

Tenant management organisations were one of the earliest manifestations of the political strategy of localism applied to restructure the delivery of public housing services and promote market-like disciplines. Tenant management enables elected community groups to take over the running of council estates, if supported by a ballot of residents, to decentralise the delivery of housing services to the locality and make changes to the public realm (Cairncross, 
Morrell et al 2002). The tenancy agreement signed by local residents provides the management organisation with its legitimacy, and defines its remit to discipline the behaviour of tenants (Flint 2004). But Christine goes beyond normative injunctions to configure this regulatory remit as the transformation of behaviour. Her aim is to recreate what Mike Davis (2006) has called 'democratic public space' in the reciprocal networks of community:

You could at one time rely on your neighbour if you were ill. Um, you can't do that anymore, because they lock themselves in and they don't want to know. And that's not, to me, that's not a community.

Christine imagines the housing estate as a network of neighbourly interaction nurtured by an ethics of care. Christine's husband Gary explains the vision that clearly motivates the couple; he uses his hands to express the estate as conceptual space; starting out with a small rectangle, then enlarging it to indicate a breach of boundaries:

Gary: A lot of people now if that's their house [indicates small space on paper] that's their space in'it? [Makes a bigger space.] That's not their space anymore, [shrinks the space] that's their space in their house. And that's why you go out here on a night, you'll not see anybody walking around, where years ago

Christine: Yeah

Gary: People used to stand at the gate and talk to other people like, 
Christine: 'Course they did

Gary articulates a desire to enlarge domestic space and to dissolve the boundary between public and private, expressing this as a strategy to breach the isolation of the home and extend its feelings of safety into the street (Clark 1994). This is a negotiation over the limits of scale and the socio-spatial positioning it enforces. In Neil Smith's (1993: 105) words this community organisation 'refuse to recognise the physical boundaries of the home but instead treat the community as a virtually borderless extension of the home'. Their strategy is to appropriate space and with it power; to upscale from home to the estate. This is a transgression of boundaries that widens the agency allotted to them and enables Christine to cast a domesticating gaze over public space and claim it as her field of care:

Christine: My dad used to stand at the gate, when he retired, and everybody knew him. Didn't they? And when my dad died they all rallied round to help me mum. You don't get that anymore. [...]

But I just want everything back to how it were. Not exactly; but to make it better for people.

In Butler's terms localism is power exerted through the formation of subjects; it constitutes the agency of the tenant management organisation and provides and circumscribes its regulatory remit. But it is also power that is assumed by the subject, a power that becomes 'the instrument of that subject's becoming' 
(Butler 1997:11). Christine's intention to 'make it better for people' is a statement of strategy which is licensed by the rationality of localism and yet exceeds its remit. Her nostalgic invocation of reciprocity provides representational space through which to envisage a public sphere that is familiar and malleable and can be rendered safe and caring. Christine has transposed the regulatory norms of the household to the management of the housing estate. She has mobilised the citational practices of domestic space to reconfigure local management as the promotion of neighbourliness and solidarity. This extension of domestic agency is essential to the construction of space as both local and democratic, as the next section explores.

\section{$\underline{\text { Constructing place as participation }}$}

The key assumption underpinning the rationality of localism is that the smallest geographical unit of governance provides the greatest opportunities for citizens to participate in decisions (Lowndes \& Sullivan 2008). There is nothing intrinsic, however, to local-scale decision-making that guarantees greater popular participation (Purcell 2006). It is the desire to achieve both local management and deeper participation that motivates communitycontrolled housing associations. These resident-led organisations took over public housing from municipal authorities, and now manage their estates from neighbourhood housing offices with locally-based staff. At a conference of social housing tenants from around the country, a group of resident directors from community-controlled housing associations identified the strategies 
essential to widening democracy at the local scale. They first pointed to the necessity for election and the accountability of collective representation:

Claire: If you are elected you can honestly say 'I am speaking on behalf of', well I hope they are, whereas you are only speaking on behalf of yourself aren't you?

Yvonne: But you've also got the right then to go out and say 'I am your elected representative, can you tell me what you want?'

Paula: And everybody knows who's on the board and you get stopped, they knock on your door, they stop you in the street. You cannot get away from them.

Paula's rueful comments here about accountability indicate the web of routine interactions, face to face encounters and daily social relations that bring democracy within reach. Community organisations base their claims on democracy not on their location but on their 'nearness' to the direct experience of people (Kearns \& Parkinson 2001). This is a spatial construction in which a discourse of neighbourliness is manifested around an invocation of locality. 'Nearness' invests place with familiarity constructed through face-to-face contact, regular encounters, routine interactions, and local knowledge. Although posited as actually-existing conditions integral to neighbourhoods by the rationale of localism, these everyday relationships have to be constructed in reiterative practice, emotional identification and 
representational space by community groups, who strive to generate collective identities around the practices of place (Martin 2003).

Paula provides an account of how her community board of 12 people tries to ensure that the residents of their high-rise housing estate in a town in southern England are engaged in decision-making. She describes both the active construction of the local scale as democratic and the performative production of local knowledge, of neighbourhood, and therefore of the local scale itself. This is partly a physical transformation; Paula tells how, prior to community control, housing staff from the local authority would never visit the estate, and residents had to make a long and expensive bus journey into the city; now the community organisation has a housing office in the centre of the estate, and:

Now the people don't have to go all the way into S[town], you know, £5 bus ride, to report something. They just walk down the stairs, or across the green, into the office.

A sense that the community-controlled housing organisation is at the heart of the estate is reproduced in Paula's words. The office is pictured at the crossroads of every route across the estate. But the 'nearness' that distinguishes the tenant directors from the previous local authority managers is constructed through participatory decision-making processes, and by encouraging an ethos that every resident matters. 
Everything we do we go out to the tenants first and we call them 'You Decides' where we put all our questions round the board room and the people come in, if they live in a high rise block, if they live in a low rise, they all get different coloured stickers and, um, this is how we, we run it. So it does work, it does work if you give power to the people.

The face to face encounters and social interaction that constitute space as place have to be actively constructed through 'neighbouring' work (Bulmer 1986), but transforming place into nearness means bringing decision-making within reach, and embedding it in the rhythms of everyday life. After describing a contested election to the board, and the creation of a series of sub-committees to involve a wider range of local people in the decisions, Paula explains the principles of participation that have inspired this community organisation.

We have people with special needs and that, two of those go around with one of the, um, Service and Performance [sub-committee] and they do a block inspection, so, it's integrating those people to make them feel 'yes you are valid'. I mean we have a lady who comes to our board meetings, she's in her 50 s with, er, learning difficulties but she makes the tea and her highlight last meeting was because we gave her a badge with her name on, you know. So it's trying to accommodate everybody, 
making everybody feel that yes you have got something to do, you are a valid member of society.

Localism provides this community organisation with the regulatory framework to take decisions on behalf of their housing estate. In delivering its authority, the community organisation makes the practices of neighbouring and domestic care central to their estate management practice (Jupp 2008). Participation in decision-making appears here as the outcome of neighbouring and as an active process of inclusion in which democracy is an essential component of nearness. The rationality of localism, with its problematic assertion that the local is inherently more democratic, has authorised spatial practices through which space can be constructed as both local and democratic.

The preceding studies have evidenced how the regulatory license of localism enables space to be domesticated and place to be rendered participative. The next sections investigate how these familiarising practices apply to the spatial transformation of power that state strategies of localism promise but fail to deliver.

\section{Rooting power in domesticity}

Localism owes a debt to the tradition of participatory democracy and embeds this uncomfortably within centralised and hierarchical systems of governance 
(Brownhill 2009). The central direction of localism, and the strengthening of state power it conceals (Fuller \& Geddes 2008), ensures that participatory democracy is kept subordinate to representative democracy, and more frequently is subsumed by the managerial discourses that have depoliticised the governance of public services, and legitimised their outsourcing and privatisation (Swyngedouw 2004; Wallace 2010). Community groups wishing to benefit from the rights of localism are dependent on the local authority for their right to become spaces of governance (CLG 2011). Their boundaries and constitutions must be designated by state power (CLG 2012b); they may be conjured up to parallel the abstract geography of executive power, or slotted into existing state structures without lines of accountability or systems of wider participation (Taylor 2007).

In a political restructuring which has promised the devolution of power to localities and celebrated the smallest scale as the most democratic, community organisations are encouraged to consider what decisions should be taken locally, and what systems of democracy would deliver the 'empowered participatory democracy' (Fung \& Wright 2003) that localism celebrates but fails to implement. London Tenants Federation is a community organisation engaged in the devolved governance arrangements of the English capital. It draws together delegates from formally constituted organisations of social housing tenants in each borough of the city and coordinates resident involvement in the London Mayor's housing strategy. Five of those delegates, all council tenants, were engaged in a discussion about how the Federation can remain accountable to its borough groups while 
operating at regional scale. In the extract below they sketch out the processes of participatory democracy that ensure the distant power of hierarchies can be rooted in the familiarity of place.

Jane: I also think that, um, there actually has to be a democratic structure

Sanjit: Hmm

Jane: So the people who are speaking know they're accountable to the people they're speaking for. I mean, for example, we, nobody in our borough can get to tenants council without having been elected first from their tenants association, then from there to their area forum, from their area forum they go to, so there's a democratic structure and every year you have an AGM, every year you have to show your accounts, every year you have to, [..] and then, you, you speak, and if you continually speak for yourself you won't get elected next time round, you know, or if you speak for yourself and people quite like you speaking for yourself because they agree with you, well then that's alright, do you know what I mean? You can't necessarily consult on every question at every moment with the people on the ground but you represent them and you go back to them and say I said that and do you agree, and do you support me?

The model of participatory democracy presented by Jane is one where decisions are made deliberatively at the most local level, and the authority delegated to other scales is limited and subject to recall. At the heart of the 
scalar decision making process is the local tenants association, a constituted group elected at annual meetings open to all residents, which assumes a mandate to speak on behalf of a defined social housing estate. Although some of these groups may in practice represent only specific constituencies, a reflexive discourse of accountability has attached to the organisational structure of collective action in social housing. Jane continues the discussion:

The thing about a tenants association is that everybody on the estate potentially can come to the tenants association, so potentially you are consulting with all of them and you're their voice and you're answerable to them. Even if we know when we turn up they're probably going to nominate the same old people. If they really disliked what we were doing, they wouldn't. They'd get us out, if we were advocating things that weren't in their interest.

In Jane's interpretation the tenants association brings decision-making into reach, and locates it in the space of 'nearness'. Residents 'turn up' routinely, but Jane indicates the opportunity for residents to pack a meeting, express their dissatisfaction and obtain redress. In this model being 'answerable' means to be within calling distance, and implies being subject to face to face challenge. Here the norms of domestic space are applied in critique of the 'stage-managed' participation that has been a feature of the community partnerships familiar to devolved governance (Allmendinger \& Haughton 2012). In Jane's words, there is no suggestion that communities are unitary 
entities or that neighbourhood consensus is easily achieved. Instead the possibility of antagonism and conflict is explicitly admitted and the empowered participatory democracy that is posited is one that enables decisions to be contested and overturned through unmediated encounters. Continuing the discussion, London Tenants Federation begin to imagine what multi-scalar decision-making structures might be like if modelled on these principles of participatory democracy:

Najinder: So what I feel is, if there should be a general trend is, the consultation process, or whatever is to be agreed upon, should start at the grass roots and then be taken forward as we go along, then you, you will get effective participation.

Sanjit: The ideal would be that there would be some sort of organisation that was based on delegates from area tenant federations like ours. Everybody here is an elected representative of a residents association, or a tenants association somewhere. And we come together and we agree things by consensus. I like to use my old, I used to be a shop steward in the film technicians union and I always used to say in meetings: 'I'm sorry, I can't take that back to my members' [laughs]. So whenever I'm in meetings I always try and think like that, okay, can I get, would I, can I get anybody else on my estate to agree to this, no? Well I can't agree to it, even if I think it's a good idea [laughs]. That. That's real democracy. 
Jane: It should be a bottom-up process like we are; it should work by consensus rather than um you know; it should recognise regional differences, because there are, you know, the problems of London are unique to London for example.

In the discussion cited above, members of this community organisation can be seen to seize the space allotted them in the locality, and to reconstruct, from the ground up, a scalar imaginary of democratic governance. They sketch out a participatory process that attempts to reconcile the primacy of place, the recognition of difference and the need for inclusion in a system of delegation that prioritises local knowledge. The active process of domesticating space observed among community organisations empowered under localism is here translated into a spatial structuring of politics imagined to bring supra-local decision-making into reach, and root power in domesticity and the routine of face to face interaction. This spatial reimagining of democracy can then be applied to debates about governance at national scale as the final section examines.

\section{Bringing democracy back home}

Spatial transformations of governance underway in most Western countries privilege the local as a natural political unit with distinct needs and the ability to address them through local agency. These strategies of localism disregard the trans-local geographies of institutional power and the structural 
inequalities that influence the politics of place (Massey 1994; Harvey 1996). Social movement theorists have emphasised the need for change at national and global scale and have called for wider campaigns enabled by networks of place-based contentious action. How these wider connections can be forged, and how local protest might envisage itself as part of a combative universal and still retain its particular identity, has been the subject of intense debate (Routledge 2003; Featherstone 2005; Cumbers, Routledge \& Nativel 2008; Nicholls 2008). The community organisations studied in this paper, ones representing social housing tenants, are networked weakly at national level through one of four organisations. None of these national bodies has more than partial support from community organisations whose commitment to a participatory democracy vested in the familiarity of 'nearness' makes it difficult for them to envisage a role for a national organisation that would not be hierarchical and authoritarian. The suspicion that surrounds the role of a national organisation, and the transfer of any functions away from the reach of the locality, becomes apparent in revisiting the discussion among members of the northern tenant management organisation featured earlier in this fieldwork. Jean, a member of the tenant management board, is keen to promote the benefits of the National Federation of Tenant Management Organisations to her colleagues.

Jean: I do think national tenants is a very good thing because everyone's telling one another their little tips. It's like you read in newspaper, um, somebody'll tell you tip how to get lipstick out of your 
thing or some chewing gum off things, it's word of mouth and little tips like that I think help you

Christine: Yeah

Jean: With what you are doing; and I think that is important. And you only get that by meeting other people and hearing what they're doing and things like that. Yeah I'm a big believer in national tenants' movement.

Jean characterises the role of a national organisation as one of providing 'little tips' and sharing experience; the symbolic language she uses here will be examined later. Gary, Christine's husband, intervenes at this point to challenge the relevance of a national movement to the locality, saying:

Gary: But should we mirror other tenants associations? You know, should we work same way as them, or should we try and find better ways of working? You know what I mean? If they come out with ideas should we take their ideas, use their ideas?

Jean: Well they come along and use yours as well; it's a movement that's a mixture.

Gary: I, I

Jean: You learn and they learn.

Gary: I don't believe in, er, mirroring other associations, I think we should build us own way, and make us name in it, we should find us own ways. 
For Gary, even the idea of networking with other organisations threatens to push decision-making out of reach; as if accountability rooted in 'nearness' necessitated the exclusion of wider mobilisation. Jean counters this challenge by returning to the gendered language of the example she used before, and explicitly appealing to Christine's (Gary's wife's) experience, to explain why a national organisation is beneficial.

Jean: Yeah but, what I'm saying, finding your own way actually, what I'm saying it's, it's like l've just been saying about lipstick and tips, so, you don't, your wife don't want to know how to get lipstick out of her top, she needs to find it out herself, but no, she would be grateful for that little tip Christine: Yeah I would Jean: Wouldn't yah? So this is what l'm saying. Tips from other people you don't have to do what they do. Just like you pass your tips what you found onto other people, you're not mirroring them, because although you've got that tip, you might find a better way round it Christine: Yeah, yeah.

The example of swapping tips on how to remove lipstick from clothes shifts this debate into a gendered space, and appeals to the scalar jump that is essential in community organisations: the extension of domestic agency into the public sphere. Jean has moved the representational space of the discussion from the board room of the tenant management organisation - a 
public body operating under delegated powers from the municipal authority to a domestic setting, where women exchange tips on household management. The national organisation is transformed accordingly from a distant and potentially intrusive entity into an informal exchange (perhaps over an imagined fence or garden gate) of household news and views. In this discussion the tenant management organisation begin to negotiate 'a politics of scale from below' (Escobar 2001: 161) through the language of domesticity and neighbouring. They suggest that national (or international) governance can be envisaged as a reciprocal process of neighbourly exchange and that networks and solidarities may be constructed through the parallel connection of domestic spaces. This is an imaginary in which hierarchical and scalar reversals are conjectured from the familiar and routine, while power is embedded within face to face interaction. The technology of localism has licensed practices in which domesticity and neighbouring become the drivers for political change and democracy is brought back home.

\section{Spatial practices of community localism}

Community localism extends a promise to devolve power and widen democratic engagement that resonates with a tradition of community action in which domestic norms have been mobilised effectively to challenge the governance of place and the organisation of social welfare. In mobilising gendered space and by asserting the politics of domestic and neighbourly care, community localism authorises a set of spatial practices through which 
the promise of empowerment can be performatively enacted and a more fundamental transformation of political space rehearsed. Four spatial practices have been identified through which community organisations can be seen to apply the technology of localism to enact place as participation and neighbouring as democratic governance. These are performative practices in which spatial norms are transposed under licence of localism and promises of devolution and empowerment are explored through the reiterative practices of lived space. Applying these practices within the juridical authority of localism community organisations appear able to challenge the restrictions of sociospatial positioning to experiment with participatory governance that is empowering and inclusive.

The community rights of localism authorise a transgression of spatial boundaries in a scalar jump that appropriates and domesticates space, so that political governance is cited according to the norms of the domestic sphere. Places can then be performed as 'nearness', as an outcome of face to face interaction, and participation can be understood and developed through the practice of neighbouring. The domestication of space enables community groups to conceive of a scalar imaginary of participative democracy in which decision-making is brought within reach and situated within routines of neighbourly interaction. In a fulfilment of the political promise of localism, these practices privilege the local as democratic and participative, applying a domestic economy of care to formal processes of election and collective representation in community management and governance. National and even global connections can be envisaged as parallel 
encounters with the familiarity of lived space to provide the basis for a translocal politics of place that might, in some circumstances, generate the wider contentions of a social movement.

In conclusion, the rationality of localism authorises the spatial production of a new public as part of a wider geography of restructured state power and the dispersal of government into governance. In England under the Localism Act, this is a process in which community organisations are awarded a disciplinary function in the management of neighbourhoods, and are licensed to make claims on space through the citation of regulatory discourses. In conflating the enforced reiteration of regulatory norms with the widening of democracy and the transfer of political power, localism unleashes the spatial imagination in an exploration of space, scale and socio-spatial positioning. The rationalities of localism privilege the familiarity of place and the agency of domestic space and provide a reiterative process through which 'the gaps and fissures' of socio-spatial positioning might be extended to bring power and decisionmaking into reach (Butler 1993:10). It would be foolish to gloss community localism as progressive, and the resident-led housing organisations featured in this research invoke a divided public from the socialised provision of welfare services. But as subjects and agents of governance they 'resist the givenness of place' (Dikec 2012: 674) and side-step the regulatory subjectivities of localism. This is a performance of localism that rehearses the spatial practices through which empowered participatory democracy might be realised and that signals a contained desire to change the political construction of space and the spatial construction of politics. 


\section{$\underline{\text { References }}$}

Abel \& M. Nelson (Eds.), Circles of Care: Work and identity in women's lives. Albany, NY: SUNY Press.

Allen, J. \& A. Cochrane (2010) Assemblages of State Power: topological shifts in the organisation of government and politics. Antipode. Vol. 42. No.5: 10711089

Allmendinger, P. \& G. Haughton (2012) Post-political spatial planning in England: a crisis of consensus? Transactions of the Institute of British Geographers. Vol. 37, No. 1: 89-103

Barnes, M. \& D. Prior (2009) Subversive Citizens: power, agency and resistance in public services. Bristol. Policy Press

Bradley, Q (2012) Proud to be a tenant: the construction of common cause among residents in social housing. Housing Studies. Vol. 27. No. 8: 11241141

Brent, Jeremy (2009) Searching for Community. Bristol. Policy Press

Brownhill, S. (2009) The Dynamics of Participation: modes of governance and increasing participation in planning. Urban Policy and Research. Vol. 27, No.4: $357-375$

Bulmer, M. (1986) Neighbours: the work of Philip Abrams. Cambridge. Cambridge University Press.

Butler, J. (1993) Bodies that Matter: on the discursive limits of sex. London. Routledge. 
Butler, J. (1997) Excitable Speech: a politics of the performative. London. Routledge

CLG (Communities \& Local Government) (2007) Tenant Empowerment: a consultation paper. Wetherby. Communities and Local Government Publications

CLG (2011) Neighbourhood Planning Regulations. London. Department for Communities and Local Government

CLG (2012) National Planning Policy Framework. London. Department for Communities and Local Government

Cairncross, L., Morrell, C., Darke, J., S. Brownhill (2002) Tenants Managing: An Evaluation of Tenant Management Organisations in England. London. Office of the Deputy Prime Minister.

Clark, H. (1994) Taking Up Space: redefining political legitimacy in NYC. Environment \& Planning A. Vol. 26: 937-955

Clarke, J. (2009) Community, Social Change \& Social Order. In: Mooney, G. \& S. Neal (eds.) Community: welfare, crime \& society. Maidenhead. Open University

Clarke, N. \& A. Cochrane (2013) Geographies and politics of localism: the localism of the United Kingdom's coalition government. Political Geography. Vol. 34: $10-23$

Cohen, P. (1997) Beyond the Community Romance. Soundings. Issue 5 Spring. $29-51$ 
Conlon, D. (2004) Productive Bodies, Performative spaces: everyday life in Christopher Park. Sexualites. Vol.7: $462-479$

Cresswell, T. (2004) Place: a short introduction.. Oxford. Blackwell

Cumbers, A., P. Routledge \& C. Nativel (2008) The Entangled Geographies of Global Justice Networks. Progress in Human Geography. Vol. 32, No. 2: 183201

Davis, Mike (2006) City of Quartz. London. Verso.

Delaney, D. \& H. Leitner (1997) The Political Construction of Scale. Political Geography. Vol. 16, No.2: 93-97

Dikec, M. (2012) Space as a Mode of Political Thinking. Geoforum. Vol. 43, No. 4: 669-676

Escobar, A (2001) Culture Sits in Places: reflections on globalism and subaltern strategies of localisation. Political Geography. Vol. 20: 139-174

Featherstone, D. (2005) Towards the Relational Construction of Militant Particularisms. Antipode. Vol. 37, No. 2: 250-271

Featherstone, D., Ince, A., Mackinnon, D., Strauss, K. \& A. Cumbers (2012) Progressive Localism \& the Construction of Political Alternatives. Transactions of the Institute of British Geographers. Vol. 37: 177-182

Flint, J. (2004) The Responsible Tenant and the Politics of Behaviour. Housing Studies, Vol.19, No.6 pp893-909

Fuller, C. \& M. Geddes (2008) Urban Governance under neo-liberalism: New Labour and the restructuring of state-space. Antipode. Vol. 40. No. 2: 252-282 
Fung, A \& E. Wright (2003) Deeping Democracy: institutional innovations in empowered participatory governance. London. Verso.

Fyfe, N. (2005) Making Space for Neo-Communitariansism? The third sector, state and civil society in the UK. Antipode. Vol.37, No.3: 536-557

Gibson, K (2001) Regional Subjections \& Becoming. Environment \& Planning D: Society \& Space. Vol. 19, No. 6: 639-667

Gregson, N. \& G. Rose (2000) Taking Butler Elsewhere: performativities, spatialities and subjectivities. Environment and Planning D: Society and Space, volume 18, pages $433-452$

Hall, S. \& D. Massey (2010) Interpreting the Crisis. Soundings. No.44, Spring: $57-71$

Harvey, D. (1996) Justice, Nature and the Geography of Difference. Oxford. Blackwell Publishing

Hildreth, P. (2011) What is Localism \& what implicatons do different models have managing the local economy. Local Economy. Vol.26, No.8: 702-714 Hoggart, Richard (1957) The Uses of Literacy. London. Chatto \& Windus. Houston, D \& L. Pulido (2002) The Work of Performativity: staging social justice at the University of South California. Environment \& Planning $D$ : Society and Space. Vol.20. No.4: 401-424

Kaiser, R \& E. Nikiforova (2008) The Performativity of Scale: the social construction of scale effects in Narva, Estonia. Environment \& Planning D: Society and Space.Vol.26: 537-562 
Kearns, A. \& M. Parkinson (2001) The Significance of Neighbourhood. Urban Studies. Vol. 38, No.12: 2103-2110

Jupp, E. (2008) The Feeling of Participation: everyday spaces and urban change. Geoforum. Vol. 39: 331-343

Jupp, E. (2010) Private \& Public on the Housing Estate. In: Mahony, N., J. Newman \& C. Barnett (eds.) Rethinking the Public. Bristol. The Policy Press: $75-90$

Lefebvre, H. (1991 [1974]) The Production of Space. Trans. D. NicholsonSmith. Oxford. Blackwell

Leitner, H., Sheppard, E. \& K. Sziarto (2008) The Spatialities of Contentious Politics. Transactions of the Institute of British Geographers. Vol.33, No.2: $157-172$

Lowndes, V. \& H. Sullivan (2008) How Low Can You Go? Rationales and challenges for neighbourhood governance. Public Administration. Vol. 86, No. 1: $53-74$

McCann, E.J. (1999) Race, Protest \& Public Space: contextualising Lefebvre in the US City. Antipode. Vol. 31, No. 2: 163-184

McCulloch, A. (1997) “You've Fucked Up the Estate \& Now You're Carrying a Briefcase!" In: Hoggett, Paul (ed.) Contested Communities: experiences, struggles, policies. Bristol. Policy Press.

Marston, S. (2000) The Social Construction of Scale. Progress in Human Geography. Vol. 24, No.2: 219-242 
Martin, D (2002) Constructing the Neighbourhood Sphere: gender and community organising. Gender, Place and Culture. Vol. 9, No. 4: 333-350

Martin, D. (2003) Place-Framing as Place Making: constituting a neighbourhood for organising and activism. Annals of the Association of American Geographers. Vol.93, No.3: 730-750

Massey, D. (1994) Space, Place \& Gender. Oxford. Polity Press

Mohan, G. \& K. Stokke (2000) Participatory development \& Empowerment: the dangers of localism. Third World Quarterly. Vol. 21, No. 2: 247-268

Mooney, G. and Neal, S. (eds.) (2009) Community: Welfare, Crime and Society, Maidenhead: Open University Press.

Newman, J (2012) Making, Contesting \& Governing the Local: women's labour and the local state. Local Economy. Vol. 27, No. 8: 846-858

Newman, J. \& J. Clarke (2009) Publics, politics and power: Remaking the public in public services. London. Sage Publications.

Newman, J., M. Barnes, H. Sullivan \& A. Knops (2004) Public Participation and Collaborative Governance. Journal of Social Policy. Vol. 33, No. 2: 203223.

Nicholls, W. (2008) Place, Networks, Space: theorising the geographies of social movements. Transactions of the Institute of British Geographers. Vol.34: 78-93

Painter, J., Orton, A., Macleod, G., Dominelli, L., Pande, R. (2011) Connecting Localism \& Community Empowerment: research review and critical synthesis 
for the ARHC Connected Community Programme. Project Report. Durham. Durham University, Dept. of Geography \& School of Applied Social Sciences.

Pickles, E. (2010) Speech to the Local Government Information Unit reception of the All Party Parliamentary Group for Local Government. London 7 June. In: Townsend, S. 'Pickles: Localism is my top priority'. Regeneration \& Renewal. [Internet] Available at < http://www.regen.net> Accessed on 7 April 2013

Polanyi, Karl (1957) The Great Transformation. Boston. Beacon Press.

Portes, A. (1998) Social Capital: its origins and applications in modern sociology. Annual Review of Sociology. Vol. 24: 1-24

Purcell. M. (2006) Urban Democracy and the Local Trap. Urban Studies. Vol. 43, No. 11: 1921-1941

Raco, M. (2003) Governmentality, subject-building, and the discourses and practices of devolution in the UK. Transactions of the Institute of British Geographers. Vol. 28. No.1: 75-95

Routledge, P. (2003) Convergence Space: process geographies of grassroots globalisation networks. Transactions of the Institute of British Geographers. Vol.28. No.3: 333-349

Smith, N. (1993) Homeless/Global: scaling places. In: Bird, J, Curtis, B., Putnam, T., Robertson, G. \& L. Tucker (eds.) Mapping the Futures. London, Routlege: 87-119

Spivak, G.C. (2010) Can the Subaltern Speak? Revised edition from the "History" chapter of Critique of Postcolonial Reason. In. Morris, R.C. (ed.) Can 
the Subaltern Speak? Reflections on the History of an Idea. New York. Columbia University Press: 21-81

Staeheli, L. (2002) Women and the Work of Community. Environment \& Planning A. Vol. 35, Part 5: 815-831

Stoker, G. (2004) New Localism, Progressive Politics \& Democracy. The Political Quarterly. Vol. 75, Supp. 1: 117-129

Swyngedouw, E. (2004) Globalisation or 'Glocalisation'? Networks, territories and rescaling. Cambridge Review of International Affairs. Vol. 17, No.1: 25-48 Taylor, M. (2007) Community Participation in the Real World: opportunities and pitfalls in new governance spaces. Urban Studies. Vol.44, No.2: 297-317 Thomas, M. (2004) Pleasure \& Propriety: teen girls and the practice of straight space. Environment \& Planning D: Society \& Space. Vol. 22: 773-789

Thrift, N \& J.D. Dewsbury (2000) Dead Geographies - and how to make them live. Environment \& Planning D: Society \& Space. Vol. 18: 411-432

Titmuss, Richard (1970) The Gift Relationship: from human blood to social policy. London. George Allen \& Unwin

Tuan, Yi-Fu (1979) Space and Place: humanist perspective. In. Gale, S. \& G. Olson (eds.) Philosophy in Geography. Dordrecht; Boston: D. Reidel Pub. Co. Tyler, M \& L. Cohen (2010) Spaces That Matter: Gender Performativity and Organisational Space. Organisation Studies. Vol.31. No.2: 175 - 198

Wallace, A. (2010) New Neighbourhoods, New Citizens? Challenging community as a framework for social and moral regeneration under New 
Labour in the UK. International Journal of Urban \& Regional Research. Vol. 34, No. 4: $805-819$

Westwood, A. (2011) Localism, Social capital and the 'Big Society'. Local Economy. Vol. 26, No. 8:690-701

Williams, F. (1993) Women \& Community. In: Bornat, J., C. Pereira, D. Pilgrim \& F. Williams (eds.) Community Care: a reader. Basingstoke. Macmillan

Williams, Raymond (1958) Culture and Society. London. Chatto \& Windus.

Williams, C. \& J. Windebank (2000) Helping Each Other Out? Community exchange in deprived neighbourhoods. Community Development Journal. Vol. 35. No.2: $146-156$

Young, Michael \& Peter Wilmot (1962) Family and Kinship in East London. Harmondsworth. Penguin. 